Short communication

\title{
Eleocharis atropurpurea (Retz.) J. Presl \& C. Presl and Eleocharis acutangula (Roxb.) Schult. (Cyperaceae): Two new distributional records for Andaman and Nicobar Islands, India
}

\author{
Sanjay Mishra*, Vivek C. P., Gautam Anuj Ekka and Lal Ji Singh \\ Botanical Survey of India, Andaman and Nicobar Regional Centre, Port Blair-744102, \\ Andaman and Nicobar, India
}

*Corresponding Author: sanjayalld74@gmail.com

[Accepted: 18 February 2017]

[Cite as: Mishra S, Vivek CP, Ekka GA \& Singh LJ (2017) Eleocharis atropurpurea (Retz.) J. Presl \& C. Presl and Eleocharis acutangula (Roxb.) Schult. (Cyperaceae): Two new distributional records for Andaman and Nicobar Islands, India. Tropical Plant Research 4(1): 77-80]

Eleocharis R.Br. is a cosmopolitan genus of the family Cyperaceae which comprises about 200 species, distributed in tropical, subtropical, and temperate regions of the world (Gonzalez-Elizondo \& Peterson 1997, Mabberley 2009). Prasad \& Singh (2002) mentioned about 21 species of this genus from India. During field expedition for the project of Flora of Kyd, James and Pitman islands, the authors came across with interesting specimens of Eleocharis from water logged field in Shoal bay area of South Andaman. On Critical study, perusal of literature and consultation of the herbarium at PBL, the specimens were identified as Eleocharis atropurpurea (Retz.) J. Presl \& C. Presl, and Eleocharis acutangula (Roxb.) Schult. A thorough scrutiny of the literature (Rao 1986, Lakshminarasimhan \& Rao 1996, Mathew 1998, Pandey \& Diwakar 2008, Murugan et al. 2016) revealed that Eleocharis atropurpurea (Retz.) J. Presl \& C. Presl has so far not been reported from the Andaman and Nicobar Islands. Kamble (2013) mistakenly determined one Eleocharis specimen collected from Andaman (Mayur Y Kamble 30664) as Eleocharis acutangula (Roxb.) Schult. However, investigation on the particular specimen housed at PBL revealed that the specimen is actually of Eleocharis spiralis (Rottb.) Roem. \& Schult. Hence, our collection of Eleocharis acutangula (Roxb.) Schult. from Shoal bay forms the first record of the species from the Andaman and Nicobar Islands.

Eleocharis atropurpurea (Retz.) J. Presl \& C. Presl in C. B. Presl, Reliq. Haenk. 1: 196. 1828; C.B. Clarke in Hook. f. Fl. Brit. Ind. 6: 627. 1893; Bhattacharya, Bull. Bot. Surv. In. 6: 208. 1964; Panigrahi et al., Bull. Bot. Surv. Ind. 11: 111. 1969; Rao \& Verma, Cyp. N. E. Ind. 25. 1982; Karthik. et al., Fl. Ind. Enum. Monocot. 48. 1989; Cook, Aqu. Wet. Pl. Ind. 127. f. 121. 1996. Scirpus atropurpureus Retz. Obs. Bot. 5: 14. 1789. (Fig. 1)

Annual herbs. Rhizome absent; roots fiberous. Stems 5-25 cm $\times 0.25-1.0 \mathrm{~mm}$, green, glabrous, erect, tufted, slender. Leaves absent; sheaths 2, ca. $1.5 \mathrm{~cm}$ long, obliquely truncate at apex, membranous, purplish below, pale brownish above, glabrous. Inflorescence solitary with terminal spikelets. Bracts absent. Spikelets ca.5.0 $\times 2.5$ $\mathrm{mm}$, ovoid to oblong-ovoid, lanceolate, subterete, brownish, turning fuscous dark in fruit, acute, wider than stem, many-flowered. Glumes ca. $1.5 \times 1.0 \mathrm{~mm}$, membranous, elliptic, oblong, loosely imbricating, muticous, keeled; keels green, sides hyaline, nerveless with purplish bands on both sides of the green keel. Perianthbristles 7 in numbers, $c a$. $1.0 \mathrm{~mm}$ long, slender, white, translucent, antrorsely scabrid, shorter than a nut, sometimes much reduced or absent. Stamens 2; anthers ca. $0.5 \mathrm{~mm}$ long, yellow, oblong, glabrous; filaments $c a$. $1.0 \mathrm{~mm}$ long, slender, glabrous, longer than anthers. Pistils $c a .1 .5 \mathrm{~mm}$ long; ovaries ca. $0.3 \mathrm{~mm}$ long, ovate, glabrous; styles ca. $0.5 \mathrm{~mm}$ long, bicleft, base discoid, glabrous; stigmas 2, ca. $0.7 \mathrm{~mm}$ long, glabrous, acuminate. Nuts $c a .0 .7 \mathrm{~mm} \times 0.5 \mathrm{~mm}$, obovoid, biconvex, smooth, glossy, shining black on maturity, stipitate at the base, truncate at the apex with grayish and flattened appendage, surface cells obscure, subquadrate, persistent minute style base, persistent perianth bristle whitish, shorter than to slightly exceeding the nut.

Flowering \& Fruiting: July-November.

Habitat: Grassy areas on the edges of waterlogged soil, open wet places. 

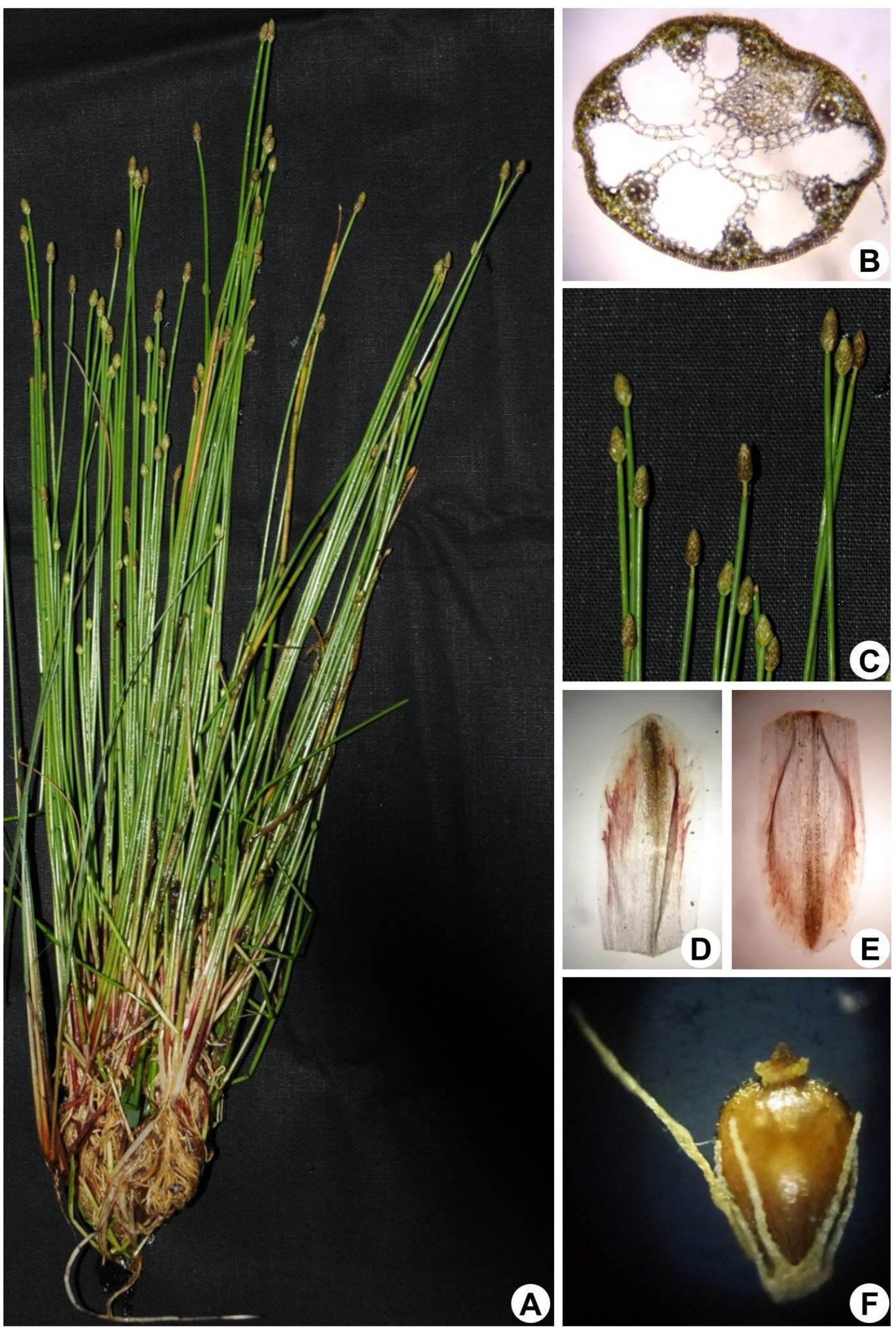

Figure 1. Eleocharis atropurpurea (Retz.) J.Presl \& C.Presl: A, Habit; B, Cross section at distal end of culm below the spikelet; C, Culms with spikelets; D, Glume, adaxial view; E, Glume, abaxial view; F, Nut. 
Distribution: Pantropical and subtropical distribution, occurring throughout Africa, Middle East, Afghanistan, China, Japan and Taiwan, Southeast Asia to Australia, North, Central and South America. India: Andaman and Nicobar Islands, Jammu and Kashmir, Delhi, Himachal Pradesh, Punjab, Rajasthan, Uttar Pradesh, West Bengal, Assam, Madhya Pradesh Gujarat, Maharashtra, Karnataka, Andhra Pradesh, Kerala, Tamil Nadu.

Specimens examined: India; Andaman and Nicobar Islands, South Andaman, Shoal Bay-12, near Government

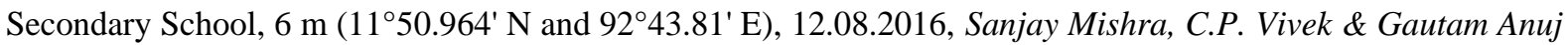
Ekka 32692 (PBL).

Taxonomic Notes: Eleocharis atropurpurea (Retz.) J. Presl \& C. Presl is easily confused with Eleocharis geniculta (L.) Roem. \& Schult., due to similar morphological appearance. But it can be distinguished from the later by the presence of tightly imbricate glumes with a green keel and whitish perianth bristles during fruiting, whereas, in E. geniculata glumes are loosely imbricate, green keel absent and perianth bristles are brownish while fruiting.

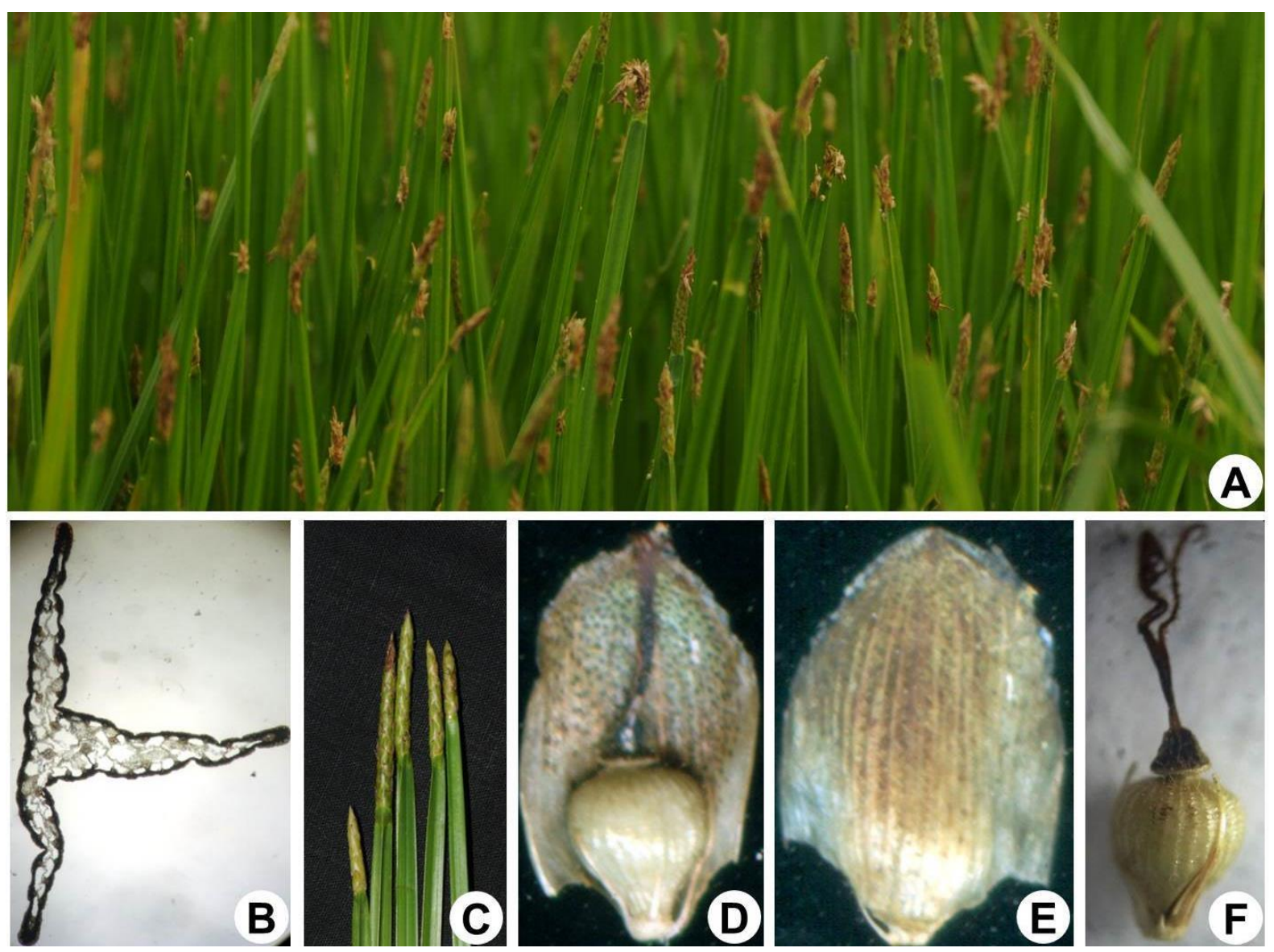

Figure 2. Eleocharis acutangula (Roxb.) Schult.: A, Habit; B, Cross section at distal end of culm below the spikelet; C, Culms with spikelets; D, Glume, adaxial view; E, Glume, abaxial view; F, Nut.

Eleocharis acutangula (Roxb.) Schult. in Roem. \& Schult., Syst. Mant. 2: 91. 1824; Kern in van Steenis, Fl. Males. 1, 7: 525. 1974; Rao \& Verma, Cyp. N.E. Ind. 23.f.9-9a. 1982; Karthik et al., Fl. Ind. Enum. Monocot. 48. 1989; Cook, Aqu. Wet. Pl. Ind. 127.f. 121 a-d. 1996; Clarke in Hook.f. Fl. Brit. Ind. 6: 626. 1893. Scirpus acutangulus Roxb. Fl. Ind. 1: 216. 1820. (Fig. 2)

Perennial herbs with $c a$. $1.0 \mathrm{~cm}$ long rhizome. Stems triquertrous, acute at apex, $30-75 \mathrm{~cm} \times 3-5 \mathrm{~mm}$. Leaves reduced to few basal sheaths; sheaths $2-3, \mathrm{ca} .8 .0 \mathrm{~cm}$ long, loose, purplish, acute, oblique at mouth, soon disintegrating, membranous, tubular, truncate. Inflorescence solitary with terminal spikelets. Bracts absent. Spikelets $c a .3 .5 \mathrm{~cm} \times 2.5 \mathrm{~mm}$, terete, cylindrical, slightly thicker than stem, acute, glaucous, greenstramineous, 8-32 flowered; rachilla persistent. Glumes ca. $6.0 \times 4.0 \mathrm{~mm}$, coriaceous, tightly imbricating, ovate, oblong, scarious margined, stramineus, red-brown dotted, several, striate, acute, obtuse at apex, spiral, caduceus, mid-nerves visible, brown with many faint nerves on both sides. Perianth-bristles 6, very unequal, $c a .2 .0 \mathrm{~mm}$ long, slightly broader at apex, brown, smallest one half to two third or as long as the nut, longest one equaling or 
exceeding the beak of nut, retrorsely scabrid, acute, base rounded. Stamens 3, rarely 2; anthers ca. $2.0 \mathrm{~mm}$ long, deep brown, linear-lanceolate, ovate-oblong, muticous, glabrous, acuminate, base rounded, connective appendage very minute; filaments $c a .4 .0 \mathrm{~mm}$ long, slender, hyaline, longer than anther, attached with pistil to the base. Pistils $c a .4 .0 \mathrm{~mm}$ long; ovaries $c a .1 .0 \mathrm{~mm}$ long, obovate, glabrous, base acuminate; styles $c a .2 .0 \mathrm{~mm}$ long, glabrous, dilated at base, with a constriction above the nut, slender; stigmas $3, c a .1 .0 \mathrm{~mm}$ long, acute, brown, fimbriate. Nuts $c a .2 .0 \times 1.0 \mathrm{~mm}$, broadly obovoid, biconvex, slightly compressed, constricted at apex into a short but distinct neck, glossy, brownish-stramineus, surface cells transversely oblong in 15-20 vertical rows on each face.

Flowering \& Fruiting: July-February.

Habitat: Shallow stagnant water in ditches and margin of ponds.

Distribution: Nepal, Myanmar, China, Sri Lanka, Malaysia, Cambodia, Laos, Philippines, Japan, Tropical Africa, Madagascar, America and Australia, India: Andaman and Nicobar Islands, Punjab, Rajasthan, Uttar Pradesh, Madhya Pradesh, West Bengal, Assam, Maharashtra, Karnataka, Andhra Pradesh, Kerala and Tamil Nadu.

Specimens examined: India; Andaman and Nicobar Islands, South Andaman, Shoal bay-12, near Government Secondary School, 6 m (11 50' 00.97" N and 92 44' 00.81" E), 12.08.2016, Sanjay Mishra, C.P.Vivek \& Gautam Anuj Ekka 32693 (PBL).

Taxonomic Notes: Eleocharis acutangula (Roxb.) Schult. has some morphological similarity with Eleocharis spiralis (Rottb.) Roem. \& Schult., but can be easily distinguished from the later by its loosely imbricating glumes which are broadly oblong or oblong ovate and obtuse to acute at apex. Whereas, glume of E. spiralis is tightly imbricating which are broadly obovate and truncate at apex. Moreover, the stem of E. spiralis is gradually narrowed towards the apex unlike in E. acutangula where the stem is more or less in same thickness from base to apex.

\section{ACKNOWLEDGEMENTS}

The authors are thankful to Dr. Paramjit Singh, Director, Botanical Survey of India, Kolkata, for providing facilities and constant support. The authors are also thankful to the Ministry of Environment, Forests and Climate Change for providing necessary facilities and support through the Director BSI, Kolkata. Thanks are also due to the Forest Department, Andaman \& Nicobar Islands, for extending logistic support during the field visit.

\section{REFERENCES}

Gonzalez-Elizondo MS \& Peterson PM (1997) A classification of and key to the supraspecific taxa in Eleocharis (Cyperaceae). Taxon 46: 433-449.

Kamble MY (2013) Eleocharis acutangula (Roxb.) Schult.(Cyperaceae): A New Record for Andaman and Nicobar Islands. Indian journal of Forestry 36(2): 253-254.

Lakshminarasimhan P \& Rao PSN (1996) Supplementary list of angiosperms recorded (1983-1993) from Andaman and Nicobar Islands. Journal of Economic and Taxonomic Botany 20: 175-185.

Mabberley DJ (2009) Mabberley's plant book, a portable dictionary of plants, their classification and uses, $3^{\text {rd }}$ Edition. Cambridge University Press.

Mathew SP (1998) A supplementary report on the flora and vegetation of Bay Islands, India. Journal of Economic and Taxonomic Botany 22: 249-272.

Murugan C, Prabhu S, Sathiyaseelan R \& Pandey RP (2016) A Checklist of Plants of Andaman and Nicobar Islands. Available from: http://bsienvis.nic.in/Database/Checklist-of-Andaman-Nicobar-Islands_24427.aspx (accessed: 10 Aug. 2016).

Pandey RP \& Diwakar PG (2008) An integrated checklist of plants in Andaman \& Nicobar Islands, India. Journal of Economic and Taxonomic Botany 32: 403-500.

Prasad VP \& Singh NP (2002) Sedges of Karnataka (India). Reprinted from Journal of Economic and Taxonomic Botany, Additional Series No. 21. Sci. Publ., Jodhpur.

Rao MKV (1986) A preliminary report on the angiosperms of Andaman and Nicobar Islands. Journal of Economic and Taxonomic Botany 8: 107-184. 